\title{
Characters of Pennisetum spp. used for the initial selection in the genetic improvement program for elephant grass ${ }^{1}$
}

\section{Caracteres de Pennisetum spp. para seleção inicial no programa de melhoramento genético do capim-elefante}

\author{
Maria da Conceição Silva²; Mércia Virginia Ferreira dos Santos \\ Mário de Andrade Lira ${ }^{4}$; Alexandre Carneiro Leão de Mello ${ }^{3}$; \\ Wellington Samay de Melo; ; José Carlos Batista Dubeux Junior ${ }^{6}$; \\ Rinaldo Luiz Caraciolo Ferreira ${ }^{3}$; Luiz Felipe Pereira Borba Carvalho ${ }^{7}$
}

\begin{abstract}
The present study was carried out at the Experimental Station of the Agronomical Institute of Pernambuco (IPA) in Itambé-PE to analyse different characters for the initial selection of Pennisetum spp. clones based on the coefficient of repeatability and the number of measurements required to predict their genotypic values (with a coefficient of determination $\mathrm{R}^{2}=0.80$ ). Considering the high number of genotypes in Phase I of the genetic improvement program and the requirement to reduce this number before progression to Phase II, it is relevant to identify characters with high genotypic values, which are easy to measure or acquire and that can be used in the initial selection. Therefore, we chose to evaluate the coefficient of repeatability and the number of measurements necessary to predict the genotypic values of 23 characters, either morphological or productive, of 472 Pennisetum spp. clones, in nonrepeated plots. The coefficient of repeatability was estimated using the components of the analysis of variance (ANOVA). Dry matter concentration, leaf blade colour, midrib colour, leaf sheath colour, and internode colour were less affected by environmental conditions, and it was possible to predict their genotypic values $\left(\mathrm{R}^{2}=0.80\right)$ with a maximum of four measurements, indicating that these characters are predictable and reliable for initial selection of Pennisetum spp.
\end{abstract}

Key words: Clones. Morphological descriptors. Hybrids. Millets. Repeatability. Dry matter content.

\section{Resumo}

O trabalho foi conduzido na Estação Experimental do Instituto Agronômico de Pernambuco (IPA), em Itambé-PE, objetivando analisar diferentes caracteres na seleção inicial de clones de Pennisetum sp. com base no coeficiente de repetibilidade e no número de medidas necessário para predição de seu valor genotípico $\left(\widehat{R}^{\mathbf{2}}=0,80\right)$. Diante do elevado número de genótipos na Fase I do programa de melhoramento e da necessidade de se reduzir quando se progride para a Fase II, é relevante a identificação de caracteres de alto valor genotípico e de fácil mensuração ou obtenção para seleção inicial. Assim, optou-se em

\footnotetext{
1 Pesquisa financiada pelo CNPq e pelo acordo IPA/UFRPE.

2 Pesquisadora, Instituto Agronômico de Pernambuco, IPA, Recife, PE, Brasil. E-mail: mcsilvaforragem@hotmail.com

3 Profs., Universidade Federal Rural de Pernambuco, UFRPE, Bolsista do CNPq, Recife, PE, Brasil. E-mail: mercia.vfsantos@ ufrpe.br; alexandre.lmello@ufrpe.br; rinaldo.ferreira@ufrpe.br

${ }^{4}$ Pesquisador do IPA e Bolsista do CNPq, Recife, PE, Brasil. E-mail: mariolira@terra.com.br

${ }^{5}$ Prof., Instituto Federal de Pernambuco, Campus Belo Jardim, Belo Jardim, PE, Brasil. E-mail: wsamay.melo@gmail.com.br

${ }^{6}$ Prof., Pesquisador da Universidade da Flórida, Campus Marianna, FL, USA. E-mail: dubeux@ufl.edu

7 Zootecnista, Mestre, Vitória da Conquista, BA, Brasil. E-mail: luisfelipeborba@hotmail.com

* Author for correspondence
} 
avaliar o coeficiente de repetibilidade e no número de medidas necessário para predição do valor genotípico de 23 caracteres, entre morfológicos e produtivos, de 472 clones de Pennisetum spp. em parcelas não repetidas. A repetibilidade foi estimada por meio dos componentes da análise de variância. Teor de matéria seca, cor da lâmina foliar, cor da nervura foliar central, cor da bainha e cor do entrenó foram menos influenciados pelas condições ambientais, sendo possível predizer o valor genotípico $\left(\widehat{R}^{\mathbf{2}}=0,80\right)$ dos mesmos com no máximo quatro medidas. É possível predizer o valor genotípico dos caracteres teor de matéria seca, cor da lâmina foliar, cor da nervura foliar central, cor da bainha e cor do entrenó com apenas quatro avaliações, classificando-os como de alta facilidade de predição e confiáveis na seleção inicial de Pennisetum spp.

Palavras-chave: Clones. Descritores morfológicos. Híbridos. Milheto. Repetibilidade. Teor de matéria seca.

\section{Introduction}

In Phase I of any genetic improvement program of forage plants, the number of genotypes is high. In order to reduce this number before progressing to Phase II, it is important to identify characters with a high genotypic value, that are easy to measure, and fast to obtain, that can be used in the initial selection.

Certain characteristics of elephant grass (Pennisetum purpureum Schum), such as productivity, quality, palatability, vigour, and resilience have created interest in the genetic improvement of this species (CUNHA et al., 2011; PITA, 2013).

The productive and morphological variability found in elephant grass cultivars (CAVALCANTE; LIRA, 2010) associated with the relative ease in crossing this species with millet (Pennisetum glaucum (L.) Leeke) (FERREIRA, 2006) facilitates the generation of superior genotypes.

The identification of superior genotypes depends on an efficient analysis of the germplasm, through which genetic differences between the species can be discriminated (SILVA et al., 2008). In this context, repeatability has been widely used by geneticists to measure the upper limit of heritability and the prediction efficiency of the genotypic value using successive measurements (SOUZA SOBRINHO et al., 2010).

The repeatability coefficient can vary according to the characteristics and genetic properties of the population, as well as the environmental conditions (CRUZ et al., 2004). Therefore, implementing only two evaluations in different years might be relevant if the goal is to identify characters having high repeatability, especially when considering evaluations carried out using visual observations, which may lead to acceleration of the selection process.

The Ministry of Agriculture (2016) introduced a list of descriptors for the elephant grass that can be visually determined, aiming to morphologically characterise new genotypes to be registered. However, the use of such descriptors in the characterisation of genotypes under selection needs to be analysed.

The objective of the present study was to analyse different characters during the initial selection of Pennisetum spp. clones based on the coefficient of repeatability and on the number of measurements (NM) required to predict their genotypic values , with a coefficient of determination of $\mathrm{R}^{2}=0.80$.

\section{Material and Methods}

The present study is part of the genetic improvement program for elephant grass, developed by the Agronomical Institute of Pernambuco (IPA) and the Federal Rural University of Pernambuco (UFRPE). This program is characterised as initial selection of Phase I for the improvement of forage plants, and was carried out at the IPA Experimental Station in Itambé-PE. The municipality of Itambé$\mathrm{PE}$ is located in the physiographic micro-region of the 'Mata Seca de Pernambuco', which experiences a tropical climate and is at an altitude of $179 \mathrm{~m}$, 
with coordinates $7^{\circ} 24^{\prime} 36^{\prime \prime} \mathrm{S}$ and $35^{\circ} 06^{\prime} 46^{\prime \prime} \mathrm{W}$ (WIKIPEDIA, 2016).

The pluviometric indices recorded during the evaluation periods were $1501.5 \mathrm{~mm}$ in 2003 and $1704.2 \mathrm{~mm}$ in 2004. The predominant soils at the IPA station are classified as Agrisol with a wavy terrain (EMBRAPA, 2006).

Chemical analysis of soil samples collected from the top $20 \mathrm{~cm}$ showed: $\mathrm{pH}=4.76 ; \mathrm{P}=12.5 \mathrm{mg} \mathrm{kg}^{-}$ 1; $\mathrm{Ca}=1.12 \mathrm{cmol}_{\mathrm{c}} \mathrm{dm}^{3-1} ; \mathrm{Mg}=0.95 \mathrm{cmol}_{\mathrm{c}} \mathrm{dm}^{3-1}$; $\mathrm{Na}=0.04 \mathrm{cmol}_{\mathrm{c}} \mathrm{dm}^{3-1} ; \mathrm{K}=0.12 \mathrm{cmol}_{\mathrm{c}} \mathrm{dm}^{3-1} ; \mathrm{Al}=$ $1.47 \mathrm{cmol}_{\mathrm{c}} \mathrm{dm}^{3-1} ; \mathrm{H}=10.98 \mathrm{cmol}_{\mathrm{c}} \mathrm{dm}^{3-1} ; \mathrm{S}=2.25$ $\mathrm{cmol}_{\mathrm{c}} \mathrm{dm}^{3-1} ; \mathrm{CEC}=14.7 \mathrm{cmol}_{\mathrm{c}} \mathrm{dm}^{3-1} ; \mathrm{V}=15.5 \%$, and $\mathrm{m}=40 \%$. Liming was performed with $3.0 \mathrm{t} \mathrm{ha}^{-1}$ dolomitic limestone with the purpose of increasing the base saturation to $60 \%$.

Planting was carried out in June 2002 using two stem/pit fractions, each having two buds, and with a spacing of $1.0 \mathrm{~m} \times 1.0 \mathrm{~m}$. We evaluated 472 progenies of the following crosses: Taiwan A-146 $\mathrm{x}$ Pusa Napier/472-76 (8 progenies), Taiwan A-146 $\times$ Pusa Napier/419-76 (22 progenies), Taiwan A-146 $\times$ Guaçu 122 (28 progenies), Taiwan A-146 × Cuba 116 (21 progenies), Taiwan A-146 × "Roxo de Botucatu" (20 progenies), Pusa Napier/472-76 $\times$ Pusa Napier/419-76 (25 progenies), Pusa Napier/472-76 $\times$ Merker $\quad \mathrm{St}^{\mathrm{a}} \quad \mathrm{Rita} / 418-76 \quad(27$ progenies), Pusa Napier/472-76 × Guaçu 122 (23 progenies), Pusa Napier/472-76 × Cuba 116 (14 progenies), Pusa Napier/472-76 x "Roxo de Botucatu" (29 progenies), Pusa Napier/419-76 $\times$ Guaçu 122 (6 progenies), Pusa Napier/419-76 × Cuba 116 (10 progenies), Pusa Napier/419-76 × "Roxo de Botucatu" (21 progenies), Merker $\mathrm{St}^{\mathrm{a}}$ Rita/418-76 × "Roxo de Botucatu" (8 progenies), self-fertilised Guaçu 122 (10 progenies), Guaçu $122 \times$ "Roxo de Botucatu" (7 progenies), Cuba 116 $\times$ "Roxo de Botucatu" (26 progenies), "Roxo de Botucatu" $\times$ CAC 262 (32 progenies), Millet 23-A $\times$ Taiwan A-146 (7 progenies), Millet 23-A $\times$ Pusa Napier/472-76 (4 progenies), Millet 23-A $\times$ Merker $\mathrm{St}^{\mathrm{a}}$ Rita/418-76 (8 progenies), Millet 23-A $\times$ Guaçu 122 (5 progenies), Millet 23-A × Cuba 116 (23 progenies), self-fertilised Cuba 116 (26 progenies), and Millet 23-A freely pollinated with Pennisetum purpureum Schum (62 progenies).

Twenty-three characters were evaluated, either visually or through measurements, on two dates: 30 May 2003 and 30 September 2004. Before each evaluation, the plants were levelled by cutting close to the ground, followed by fertilisation with $100 \mathrm{~kg}$ $\mathrm{ha}^{-1}$ of $\mathrm{K}_{2} \mathrm{O}$ as potassium chloride and $60 \mathrm{~kg} \mathrm{ha}^{-1}$ $\mathrm{P}_{2} \mathrm{O}_{5}$ as triple superphosphate. In the initial phase of plant growth (15 days after cutting), the equivalent of $50 \mathrm{~kg} \mathrm{~N} \mathrm{ha}^{-1}$ was added using urea as the source.

In the period between evaluations, the plants were subjected to frequent cuttings, with the aim to achieve other objectives of the referred improvement program not included in the present study. As supplementary information, it is worthwhile to mention that the "seleção Itambé-2006" genotype, which originated in the homonymous area, is currently part of the IPA's Active Germplasm Bank of Pennisetum spp. project, and is still under evaluation for use in the improvement program (PITA, 2013; SILVA et al., 2013).

The characters obtained through measurements included: dry matter production ( $\mathrm{kg}$ tussock $\left.\mathrm{k}^{-1}\right)$, dry matter concentration (\%), plant height $(\mathrm{m})$, and the number of basal tillering (tussock ${ }^{-1}$ ). Plant height was determined using a tape measure, measuring from ground level to the tip of the highest noncurved leaf, and basal tillering was determined by counting the number of basal tillers per tussock. Dry matter concentration was obtained by drying (at 65 ${ }^{\circ} \mathrm{C}$ ) three tiller samples. Dry matter production per tussock was determined by multiplying the weight of the forage collected per tussock by the dry matter concentration.

Fifteen descriptors for elephant grass (MINISTÉRIO DA AGRICULTURA, 2016) were analysed using the scales presented in Table 1. Susceptibility to diseases was determined using grade 1 for high susceptibility, grade 2 for intermediate susceptibility, grade 3 for low susceptibility, and grade 4 for non-susceptibility. 
Table 1. List of descriptors used and their respective grading scales.

\begin{tabular}{lc}
\hline Descriptors & Grading scale \\
\hline & \\
Plant height & 3 (Low); 5 (Intermediate); 7 (High); 9 (Very high) \\
Tillering & 3 (Low); 5 (Intermediate); 7 (High); 9 (Very high) \\
Stem diameter & 3 (Thin); 5 (Intermediate); 7 (Thick) \\
Internode length & 3 (Short); 5 (Intermediate); 7 (Long) \\
Growth habit & 1 (Erect); 3 (Semi-erect); 5 (Open) \\
Foliar blade position & 1 (Erect); 3 (Semi-erect); 5 (Open) \\
Midrib width & 3 (Narrow); 5 (Intermediate); 7 (Broad) \\
Foliar blade colour & 1 (Whitish); 3 (Green); 5 (Purple) \\
Midrib colour & (Green); 2 (Yellow-green); 3 (Purple-green); 4 (Purple) \\
Leaf sheath colour & 1 (Whitish); 2 (Yellowish); 3 (Green); 4 (Green-purple); 5 (Purple) \\
Internode colour & 3 (Yellowish); 5 (Green); 7 (Green-purple); 9 (Purple) \\
Foliar blade length & 3 (Short); 5 (Intermediate); 7 (Long) \\
Leaf sheath porosity & 1 (Absent); 3 (Low); 5 (High) \\
Leaf sheath pilosity & 1 (Absent); 3 (Low); 5 (Intermediate); 7 (High) \\
Pilosity of the adaxial leaf surface & 1 (Absent); 3 (Low); 5 (Intermediate); 7 (High); 9 (Very high) \\
\hline
\end{tabular}

Source: Ministério da Agricultura (2016).

The elephant grass descriptors are suitable for 90-day-old plants (MINISTÉRIO DA AGRICULTURA, 2016). However, as this species is usually used upon cutting after only 56 to 60 days of growth (SANTOS et al., 2010a), we chose to evaluate 60-day-old plants to observe the behaviour of other characters of interest at the referred age.

The stem diameter and internode length descriptors were analysed at the middle fraction of the stem. The basal and axillary tillering descriptors were evaluated as proportions of the total tillering; therefore, a progeny with a low total tillering could still present high basal or axillary tillering, as long as the majority of the tillers were of one type. The coefficient of repeatability was estimated using components of the analysis of variance (RESENDE, 2002).

The number of measurements (NM) required to predict the real value of the genotypes was estimated based on the evaluations carried out, taking into account a pre-established coefficient of determination $\left(\mathrm{R}^{2}\right)$ of 0.80 . This criterion was based on Cruz et al. (2004), who consider this $\mathrm{R}^{2}$ a suitable value to estimate the experimental NM, when the genotypic value is estimated through the coefficient of repeatability of certain characters.

\section{Results and Discussion}

The majority of the characters presented a coefficient of repeatability below 0.60 (Table 2 ), indicating behavioural variations between measurements and creating the need for a high $\mathrm{NM}$ in order to predict genotypic values (SOUZA SOBRINHO et al., 2010). The high irregularity between measurements in the present study was associated with the plant's susceptibility to diseases, which presented a coefficient of repeatability of 0.02 (Table 2).

The low repeatability found for disease susceptibility possibly results from the fact that the occurrence of leaf spot in Pennisetum spp. clones in the analysed region is more frequent during the rainy periods of the year (SILVA, 2006). In this context, the selection of resistant genotypes must be carried out during periods when the occurrence of diseases is more frequent, even under controlled conditions, such as glass houses. In 1995, in the 
same location where the present study was carried out, leaf spot was detected on elephant grass for the first time, and it was caused by the fungal pathogen Bipolaris sacchari (Syn. Helminthosporium sacchari). The Cameroon, Merker Mexico, and "Roxo de Botucatu" varieties are resistant to this fungus (REIS et al., 1997).
Daher et al. (2004) evaluated 17 elephant grass clones in 12 cutting conditions, and estimated that nine measurements are required to genetically predict $\left(\mathrm{R}^{2}=0.80\right)$ dry matter production, an estimate that was close to that found in the present study (Table 2).

Table 2. Estimates of the coefficients of repeatability $\left(\hat{\rho}^{\mathbf{2}}\right)$ and determination $\left(\mathrm{R}^{2}\right)$, and of the number of measurements (NM) required for the prediction of characters evaluated in 472 clones of Pennisetum spp. from Itambé-PE.

\begin{tabular}{lcccc}
\hline Feature & $\hat{\rho}^{\mathbf{2}}$ & $\left(\mathrm{R}^{2}\right)$ & $\mathrm{NM}$ & Character amplitude \\
\hline Dry matter production (kg) & 0.31 & 0.47 & 11 & $0.007-1.86$ \\
Dry matter concentration (\%) & 0.65 & 0.79 & 4 & $12.10-49.04$ \\
Plant height (m) & 0.20 & 0.35 & 18 & $0.6-3.0$ \\
Susceptibility to diseases (grade) & 0.02 & 0.04 & 443 & $1.0-5.0$ \\
Basal tillering (no. tussock ${ }^{-1}$ ) & 0.55 & 0.71 & 5 & $1.0-112$ \\
Total tillering (grade) & 0.41 & 0.58 & 8 & $1.0-9.0$ \\
Basal tillering (grade) & 0.22 & 0.36 & 16 & $1.0-8.0$ \\
Axillary tillering (grade) & 0.11 & 0.20 & 34 & $1.0-7.0$ \\
Plant height (grade) & 0.21 & 0.33 & 17 & $1.0-7.0$ \\
Internode length (grade) & 0.45 & 0.62 & 7 & $1.0-8.0$ \\
Stem diameter (grade) & 0.29 & 0.45 & 12 & $1.0-7.0$ \\
Growth habit (grade) & 0.09 & 0.17 & 42 & $1.0-7.0$ \\
Foliar blade position (grade) & 0.48 & 0.65 & 6 & $1.0-5.0$ \\
Foliar blade width (grade) & 0.25 & 0.40 & 14 & $3.0-7.0$ \\
Midrib width (grade) & 0.18 & 0.31 & 20 & $1.0-7.0$ \\
Foliar blade colour (grade) & 0.85 & 0.92 & 3 & $1.0-5.0$ \\
Midrib colour (grade) & 1.00 & 1.00 & 2 & $1.0-5.0$ \\
Leaf sheath colour (grade) & 0.81 & 0.90 & 3 & $1.0-7.0$ \\
Internode colour (grade) & 0.77 & 0.87 & 3 & $1.0-9.0$ \\
Foliar blade length (grade) & 0.26 & 0.41 & 13 & $3.0-7.0$ \\
Leaf sheath porosity (grade) & 0.13 & 0.23 & 29 & $1.0-7.0$ \\
Leaf sheath pilosity (grade) & 0.39 & 0.56 & 8 & $1.0-7.0$ \\
Pilosity of the adaxial leaf surface (grade) & 0.07 & 0.13 & 55 & $1.0-7.0$ \\
\hline
\end{tabular}

$\mathrm{NM}=$ Number of measurements required to predict the real value of the genotype based on a pre-established coefficient of determination $\left(\mathrm{R}^{2}\right)$ of 0.80 .

The low correlation between measurements might be an indication of low heritability. Characters that demonstrate high $(>80 \%)$ broad sense heritability are shown to be less affected by environmental factors than those that show low heritability (CAVALCANTE et al., 2012). The NM required to genetically predict the dry matter production (Table 2) is close to the value observed by Lédo et al. (2008) in Panicum maximum (13 to
14 evaluations), varying according to the method utilised.

Elephant grass tillering dynamics is affected by the post-grazing stubble height and the population density is associated with the tiller class, the evaluation period, and the interaction between these variables (CARVALHO et al., 2006), as well as with the management strategy adopted (CUNHA et al., 2011). Such dynamics does not 
allow for reliable predictions as they have a low NM (Table 2). However, it constitutes a feature with great relevance in the selection process, i.e., basal tillering is the basis of elephant grass exploitation under cutting conditions, especially due to the fundamental importance this feature demonstrates for tussock regeneration and expansion (DUBEUX JUNIOR; MELLO, 2010).

The time of evaluation can also affect the determination of some characters. In general, between 5 A.M. and 7 A.M., it was easier to visually determine the porosity of the leaf sheath and the colour of the plants. The low intensity of sunlight during this time aids in observing the different shades of green, and the presence of moisture facilitates the porosity quantification. Porosity is also more visible on purplish coloured than on green coloured plants.

Notably, from the present study it was found that it is possible to predict the genotypic values (based on those characters with $\mathrm{R}^{2} \geq 0.80$ ) with a maximum of four measurements using the following characters: dry matter concentration, foliar blade colour, midrib colour, leaf sheath colour, and internode colour (Table 2). Nevertheless, among these characters, dry matter concentration presents the highest relevance considering the forage aspect, and in the context of morphological characterisation.

Forage species with dry matter concentration below $25 \%$ require supplementation with additives to mitigate problems inherent to the silage process (SANTOS et al., 2010b; PERIM et al., 2014). Because of this, the ease of predicting the genotypic value presented by the dry matter in the present study, associated with amplitude between 12.10 and $49.04 \%$, enables the selection of Pennisetum spp. clones with dry matter content suitable to the silage process (Table 2).

Millet has been used to transfer characteristics such as resistance to drought, rusticity, and grass quality, through interspecific hybridisation (LIRA et al., 2010). This hybridisation has also been proved to be important for the production of genotypes with dry matter concentration above $30 \%$ (SILVA, 2006), enabling the generation of genotypes suitable for silage.

The finding that with a maximum of four measurements it is possible to predict the genotypic value $\left(\mathrm{R}^{2}=0.80\right)$ of the characters dry matter concentration, foliar blade colour, midrib colour, leaf sheath colour, and internode colour, enables their classification as characters that are very easy to predict (SILVA, 2006).

Using conventional methods such as measurements of internode height and length, and counting (tillering), it was possible to stipulate patterns for those characters with regard to the descriptors (grading scales) of the evaluated genotypes after 60 days of growth. We considered genotypes of low $(<1 \mathrm{~m})$, intermediate $(\geq 1 \mathrm{~m}$ and $\leq 2 \mathrm{~m})$, and high $(\geq 2 \mathrm{~m})$ statures. Genotypes of low $\left(<20\right.$ tillers tussock $\left.{ }^{-1}\right)$, intermediate $(\geq 20$ and $\leq 50$ tillers tussock $\left.{ }^{-1}\right)$, high $(>50$ and $\leq 100$ tillers tussock $\left.^{-1}\right)$, and very high $\left(>100\right.$ tillers tussock $\left.{ }^{-1}\right)$ tillering, short internode $(<5 \mathrm{~cm})$, intermediate internode $(\geq 5 \mathrm{~cm} \leq 20 \mathrm{~cm})$, and long internode ( $>$ $20 \mathrm{~cm})$.

\section{Conclusions}

Among the evaluated characters in the present study, dry matter concentration, foliar blade colour, midrib colour, leaf sheath colour, and internode colour were the least affected by the environmental conditions, and are therefore reliable as tools in the phenotypic selection of Pennisetum spp.

It is possible to predict the genotypic values $\left(\mathrm{R}^{2}=0.80\right)$ of these characters using only four measurements. For this reason, they are classified as easy to predict among the evaluated genotypes.

The genetic variability of the dry matter concentration enables the selection of genotypes suitable for silage in Phase I of the Pennisetum spp. improvement program. 


\section{Acknowledgement}

We would like to thank the entire technical team involved in the performance of the present study, both at the Federal Rural University of Pernambuco and at the Agronomical Institute of Pernambuco.

\section{References}

CARVALHO, C. A. B.; PACIUllo, D. S. C.; ROSSIELlO, R. O. P.; DERESZ, F. Dinâmica do perfilhamento em capim-elefante sob influência da altura do resíduo pós-pastejo. Pesquisa Agropecuária Brasileira, Brasília, v. 41, n. 1, p. 145-152, 2006.

CAVALCANTE, M.; LIRA, M. A. Variabilidade genética em Pennisetum purpureum Schumacher. Revista Caatinga, Mossoró, v. 23, n. 2, p. 153-163, 2010.

CAVAlCANTE, M.; LIRA, M. A.; SANTOS, M. V. F.; PITA, E. B. A.; FERREIRA, R. L. C.; TABOSA, J. N. Coeficiente de repetibilidade e parâmetros genéticos em capim-elefante. Pesquisa Agropecuária Brasileira, Brasília, v. 47, n. 4, p. 569-575, 2012.

CRUZ, C. D.; REGAZZI, A. J.; CARNEIRO, P. C. S. Modelos biométricos aplicados ao melhoramento genético. 3. ed. Viçosa: UFV, 2004. 480 p.

CUNHA, M. V.; LIRA, M. A.; SANTOS, M. V. F.; FREITAS, E. V.; DUBEUX Jr., J. C. B.; MELLO, A. C. L; MARTINS, K. G. R. Association between the morphological and productive characteristics in the selection of elephant grass clones. Revista Brasileira de Zootecnia, Viçosa, MG, v. 40, n. 3, p. 482-488, 2011.

DAHER, R. F.; MALDONADO, H.; PEREIRA, A. V.; AMARAL JUNIOR, A. T.; PEREIRA, M. G.; FERREIRA, C. F.; RAMOS, S. R. R.; TARDIN, F. D.; SILVA, M. P. Estimativas de parâmetros genéticos e de coeficientes de repetibilidade de caracteres forrageiros em clones de capim-elefante (Pennisetum purpureum Schum). Acta Scientiarum, Maringá, v. 26, n. 4, p. 483490, 2004.

DUBEUX JUNIOR, J. C. B.; MELLO, A. C. Aspectos morfofisiológicos do capim-elefante. In: LIRA, M. A.; SANTOS, M. V. F.; DUBEUX JUNIOR, J. C. B.; MELLO, A. C. Capim-elefante: fundamentos e perspectivas. Recife: IPA/UFRPE, 2010. p. 51-67.

EMPRESA BRASILEIRA DE PESQUISA AGROPECUÁRIA - EMBRAPA. Centro Nacional de Pesquisa de Solos. Sistema Brasileiro de Classificação de Solos. 2. ed. Rio de Janeiro: Embrapa Solos, 2006. 306 p.
FERREIRA, P. V. Melhoramento de plantas. Maceió: UFAL, 2006. $856 \mathrm{p}$.

LÉDO, F. J. S.; PEREIRA, A. V.; SOUZA SOBRINHO, F. de; AUAD, A. M.; OLIVEIRA, J. S. e. Estimativas de repetibilidade para caracteres forrageiros em Panicum maximum. Ciência e Agrotecnologia, Lavras, v. 32, n. 4, p. 1299-1303, 2008.

LIRA, M. A.; CUNHA, M. V.; PEREIRA, A. V. Melhoramento genético do capim-elefante. In: LIRA, M. A.; SANTOS, M. V. F.; DUBEUX JUNIOR, J. C. B.; MELLO, A. C. Capim-elefante: fundamentos e perspectivas. Recife: IPA/UFRPE, 2010. p. 31-48.

MINISTÉRIO DA AGRICULTURA. Instruções para execução dos ensaios de distinguibilidade, homogeneidade e estabilidade de cultivares de capim elefante Pennisetum purpureum Schum. e híbridos interespecíficos com Pennisetum spp. Diário Oficial [da] República Federativa do Brasil, Brasília, 16 abr. 2001, Seção 1, p. 10. Disponível em: <http://www.agricultura. gov.br/arq_editor/file/vegetal/RegistroAutorizacoes/ Formularios $\% 20$ Prote $\% \mathrm{C} 3 \% \mathrm{~A} 7 \% \mathrm{C} 3 \% \mathrm{~A} 3 \mathrm{o} \% 20$ Cultivares/CAPIM_ELEFANTE_US.doc $>$. Acesso em: 11 abr. 2016.

PERIM, R. C.; PINHO COSTA, K. A. de; EPIFANIO, P. S.; SOUZA, W. F.; FRANCISCHINI, R.; TEIXEIRA, D. A. A.; SANTOS JUNIOR, D. R. Fermentative and bromatological characteristics of piata palisadegrass ensiled with energetic brans. American Journal of Plant Sciences, Irvine CA, v. 5, n. 7, p. 942-954, 2014.

PITA, E. B. A. F. Caracterização do Pennisetum purpureum Schum. e de seus híbridos com o Pennisetum glaucum (L.) (R. Brown) selecionados no Semiárido de Pernambuco. 2013. Dissertação (Mestrado em Zootecnia) - Universidade Federal Rural de Pernambuco, Recife.

REIS, A.; DUBEUX JUNIOR, J. C. B.; MELO FILHO, R. M.; MENEZES, M. Mancha ocular do capim elefante em Pernambuco-Brasil e seleção de variedades com resistência à doença. Summa Phytopathologica, Botucatu, v. 23, n. 3-4, p. 231-235, 1997.

RESENDE, M. D. V. Genética biométrica e estatística no melhoramento de plantas perenes. Brasília: EMBRAPA Informação e Tecnologia, 2002. 975 p.

SANTOS, M. V. F.; DUBEUX JUNIOR, J. C. B.; MELLO, A. C. Formação e manejo de capineiras. In: LIRA, M. A.; SANTOS, M. V. F.; DUBEUX JUNIOR, J. C. B.; MELLO, A. C. Capim-elefante: fundamentos e perspectivas. Recife: IPA/UFRPE, 2010b. p. 145-162. 
SANTOS, M. V. F.; GÓMEZ, C. A. G.; PEREA, J. M.; GARCÍA, A.; GUIM, A.; PÉREZ, H. M. Fatores que afetam o valor nutritivo da silagem de forrageiras tropicais. Archivos de Zootecnia, Córdoba, v. 59, n.1, p. 25-43, 2010a.

SILVA, M. C. Avaliação de descritores morfológicos e seleção de diferentes tipos de progênies de Pennisetum sp. 2006. Tese (Doutorado em Zootecnia) - Universidade Federal Rural de Pernambuco, Recife.

SILVA, M. C.; PITA, E. B. A. F.; FREITAS, E. V.; LIRA, M. A.; SANTOS, M. V. F.; SANTOS, D. C.; PEREIRA, V. L. A.; MESQUITA, F. L. T. Seleção de Clones de Pennisetum sp. adaptados ao Semiárido pernambucano. In: CONGRESSO BRASILEIRO DE MELHORAMENTO DE PLANTAS, 7., 2013, Uberlândia. Anais... Uberlândia: SBMP, 2013. p. 579-583. Disponível em: <http://www. sbmp.org.br/7congresso/anais> Acessado em: 19 maio 2016.
SILVA, M. C.; SANTOS, M. V. F.; LIRA, M. A.; MELLO, A. C. L.; FREITAS, E. V.; SANTOS, R. J. M.; FERREIRA, R. L. C. Ensaios preliminares sobre autofecundação e cruzamentos no melhoramento do capim-elefante. Revista Brasileira de Zootecnia, Viçosa, MG, v. 37, n. 3, p. 401-410, 2008.

SOUZA SOBRINHO, F.; PEREIRA, A. V.; LEDO, F. J. S.; BOTREL, M. A.; OLIVEIRA, J. S.; XAVIER, D. F. Avaliação agronômica de híbridos interespecíficos entre capim-elefante e milheto. Pesquisa Agropecuária Brasileira, Brasília, v.40, n. 9, p.873-880, 2005.

WIKIPEDIA. Itambé Pernambuco. Itambé: MediaWiki, 2016. Disponível em: <https://pt.wikipedia.org/wiki/ Itamb\%C3\%A9_\%28Pernambuco\%29> Acesso em: 11 abr. 2016. 